\title{
Mass Density
}

National Cancer Institute

\section{Source}

National Cancer Institute. Mass Density. NCI Thesaurus. Code C75762.

A measure of the compactness of a substance, expressed as its mass per unit volume. 